\title{
Sonhos tirânicos e uma poção mágica para as opressões na cabeça de Cármides no diálogo (homônimo) de Platão
}

\author{
Tyrannical dreams and a magic potion for Carmides's head in \\ Plato's (homonymous) dialogue
}

\section{Bianca Vilhena Campinho Pereira*}

Resumo: Sabendo que Cármides sofria com dores na cabeça pela manhã, Sócrates se oferece para curar a enfermidade do jovem e, em busca do fármaco para o tratamento, conta que, enquanto esteve em Potideia, recebera o ensinamento de certas práticas mágicas de um discípulo de Zalmoxis. Possíveis causas para as opressões na cabeça de Cármides já foram aventadas, como, por exemplo, a ressaca da embriaguez e a própria intemperança, objeto de análise do diálogo. 0 nosso propósito neste artigo e sugerir a hipótese de que a molestia se deve à qualidade de seus sonhos, destacando, dentre algumas práticas caracterizadas como mágicas, aquela que visa à cura por intermédio da excursão alçada pelo sono. Para corroborar a nossa hipótese, abordaremos passagens da República em que Platão, ao tratar da transformação do homem democrático em tirânico, menciona a psicologia dos sonhos.

Palavras-chave: Cármides; República; Sonhos; Tirania; Magia

Abstract: Upon learning that Carmides suffered from headaches in the morning, Socrates offers to cure the young man's illness and, searching for treatment, says that recently he had received the teaching of certain magical practices from a disciple of Zalmoxis. Possible causes for the oppression in Carmides's head have already been suggested, such as a hangover and the intemperance itself, object of analysis of the dialogue. Our purpose in this article is to suggest the hypothesis that the disease is due to the quality of your dreams, highlighting, among some practices characterized as magical, that which aims to cure through the excursion raised by sleep. In order to corroborate our hypothesis, we will approach some passages from the Republic in which Plato, dealing with the democratical man's transition into tyrannical, mentions the psychology of dreams.

Keywords: Carmides; Republic; Dreams; Tyranny; Magic

"Somos dessa matéria de que os sonhos são feitos.

E a nossa vida breve é circundada pelo sono."

Tempestade, William Shakespeare

\section{As opressões na cabeça de Cármides: a hipótese do sonho}

$\mathrm{Na}$ abertura do Cármides, Sócrates, o narrador, conta que, ao retornar da batalha de Potideia, após tão longo tempo distante de Atenas, resolve visitar lugares que habitualmente frequentava e, assim, dirige-se à palestra de Táureas. Chegando lá, após responder questões relativas à guerra, quer saber a respeito do estado da filosofia e dos jovens que se destacavam. Crítias, lá presente, faz referência a Cármides como aquele considerado o mais belo dos jovens (154a), além de conhecido pela inclinação filosófica, pelo temperamento poético (154e) e por sua temperança $(157 \mathrm{~d})$. Em seguida, conta a Sócrates que o rapaz andava indisposto ( $\alpha \sigma \theta \varepsilon v \varepsilon i ́ \alpha \varsigma)$ e com a cabeça a oprimi-lo ao levantar-se pela manhã. "Ultimamente

*Doutora em Filosofia pela Pontifícia Universidade Católica do Rio de Janeiro, Rio de Janeiro, RJ. O presente trabalho foi realizado com apoio do CNPq, Conselho Nacional de Desenvolvimento Científico e Tecnológico - Brasil. E-mail: biacampinho@hotmail.com ORCID: https://orcid.org/0000-0003-3404-854X 


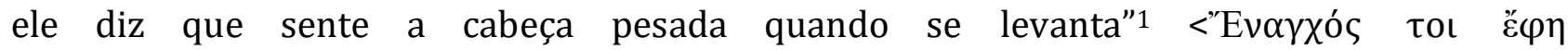

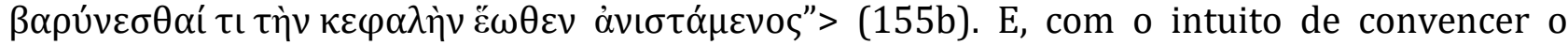
jovem a reunir-se com eles, pergunta se Sócrates incomodar-se-ia em fingir ao jovem conhecer um remédio para os incômodos da cabeça. Após a entrada radiante e desconcertante de Cármides - e de ter anunciado interesse em examinar e desnudar a alma do jovem -, Sócrates dispõe-se na tentativa de curar o que oprime a cabeça do rapaz e conta que haveria certa folha que deveria ser usada com certa fórmula mágica, sem a qual a folha não produziria efeito (155e).

Na sequência, Sócrates afirma que é sabido que bons médicos, quando consultados a respeito de dores nos olhos, não os tratam isoladamente, sendo preciso, simultaneamente, tratar da cabeça e de todo o corpo, pois deve-se curar a parte juntamente com o todo (156c). E revela ao jovem que, enquanto esteve em Potideia, um médico trácio, discípulo de Zalmoxis $^{2}$, ensinou-lhe certas práticas mágicas capazes até mesmo de conferir a imortalidade (156d). Teria sido ele, o trácio, que lhe teria indicado o ensinamento de que, assim como não é possível a cura dos olhos sem a da cabeça, nem a da cabeça sem a do corpo, não seria possível tratar do corpo sem tratar da alma, pois não poderia ir bem a parte, quando vai mal o todo.

É da alma, declarou, que saem todos os males e todos os bens do corpo e do homem em geral, influindo ela sobre o corpo como a cabeça sobre os olhos. É aquela, por conseguinte, que antes de tudo precisamos tratar com muito carinho, se quisermos que a cabeça e todo o corpo fiquem em bom estado. As almas, meu caro, são tratadas com certas fórmulas de magia; essas fórmulas são os belos argumentos. Tais argumentos geram a temperança e, uma vez presente a temperança, é muito fácil promover a saúde da cabeça e de todo o

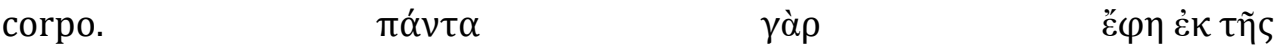

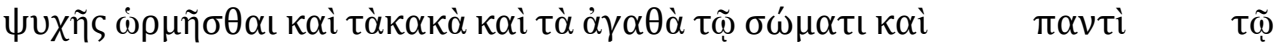

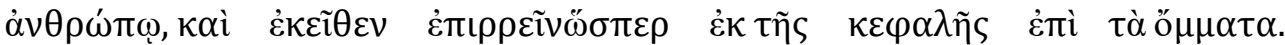

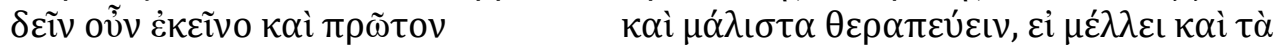

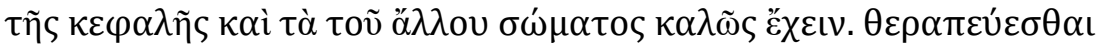

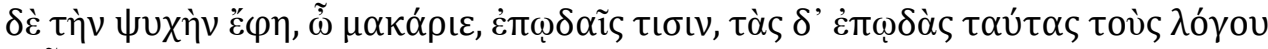

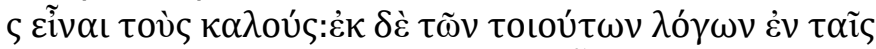

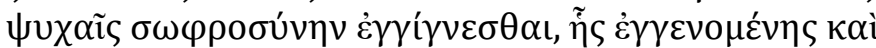

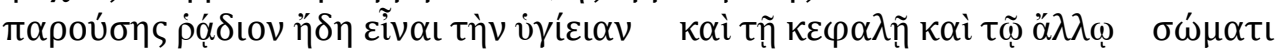

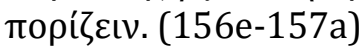

Segundo os ensinamentos do médico trácio, do mesmo modo que não se deve cuidar dos olhos independentemente da cabeça, nem cuidar da cabeça independentemente do corpo, não se deve cuidar do corpo independentemente da alma. Ademais, é a alma a

1 Todas as traduções do Cármides são de Carlos Alberto Nunes.

2 O relato em torno de Zalmoxis encontramos originariamente nas Histórias de Heródoto (4, vv. 93-96). Nas Histórias, a figura de Zalmoxis aparece sob duas variantes: uma a partir da crença dos getas; outra a partir dos gregos que viviam na Trácia. Para estes, Zalmoxis era um homem que fora escravo de Pitágoras; para os primeiros, ele era um deus ou agente cósmicos de cura social, capaz de conferir a imortalidade. Segundo a variante, enquanto os trácios choravam a sua morte, Zalmoxis teria estado em uma casa subterrânea por três anos e, quando reapareceu, tornou credíveis as coisas que tinha ensinado, dentre elas, que depois da morte se volta a viver. A 'câmara subterrânea', para onde ele teria ido durante seu período de morte, para de lá retornar à vida, e a imagem da catábase indicam provações que expressam uma espécie de ritual contra as intempéries e a própria morte, fundamentando um poder de cura adquirido depois de tais experiências. Conforme o relato de Heródoto, os xamãs, magos trácios que governavam as tribos em seu nome, imitavam a hibernação de Zalmoxis retirando-se para dentro de cavernas por longos períodos em que caíam em transe e quando despertavam narravam as visões tidas. Parece interessante, ademais, como indica a própria hibernação, lembrarmo-nos do parentesco difundido na cultura grega entre o sono e a morte, habitualmente retratados como irmãos pela mitologia. 


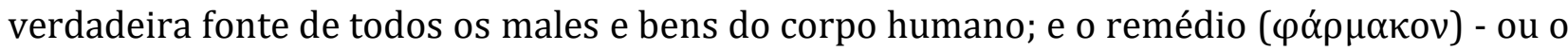
veneno - para as almas são os encantamentos. 0 corpo é parte da alma, assim como a cabeça é parte do corpo e os olhos, partes da cabeça. Quando se cuida do todo, cuida-se por extensão da parte, cuidando-se da alma cuida-se do corpo, da cabeça e dos olhos, pois estes dela dependem. A relação entre todo e parte, alma e corpo, cabeça e olhos, segundo observa Robinson $^{3}$ acerca desta passagem, não seria de adição ou subtração, mas a relação filosoficamente mais respeitável da implicação. Sendo assim, é presumível supor que, curando-se a cabeça de Cármides, o encantamento socrático ${ }^{4}$ considera-se capaz de curar também os olhos de Cármides, o que significa dizer que seria possível alterar a visão do rapaz. Quiçá, lembrando que as queixas relatas por Cármides dizem respeito a dores na cabeça que lhe ocorrem quando pela manhã se levanta, podemos inferir que Sócrates arroga-se capaz de alterar as visões oníricas do jovem. 5 Se o olho é aquilo que redimensiona a cabeça e os pensamentos, o corpo cumprirá, no diálogo, a mesma função em relação à alma, (re)posicionando-a diante da realidade, e vice e versa.

Embora explícito apenas na República, julgamos que, neste diálogo considerado de juventude, a filosofia socrático-platônica, reivindicando a cura, quer reputar-se capaz de transformar não apenas a vida (supostamente) da vigília, mas também os sonhos dos homens. E, neste sentido, segundo a hipótese que buscaremos explicitar, Sócrates, aqui, estaria aproveitando-se tanto das práticas medicinais de encantamento ditas xamânicas ou mágicas, quanto das práticas medicinais asclepianas, ${ }^{6}$ cuja concepção de cura remete aos

\section{ROBINSON, A psicologia de Platão, 44.}

4 Sobre a capacidade de Sócrates de encantar seus interlocutores, várias menções podem ser encontradas ao longo do corpus platônico. Para dar apenas alguns exemplos: no Mênon, o aluno de Górgias, afirmando que já ouvira dizer sobre como Sócrates leva a si mesmo e a todos a aporias, confessa estar ele mesmo enfeitiçado por

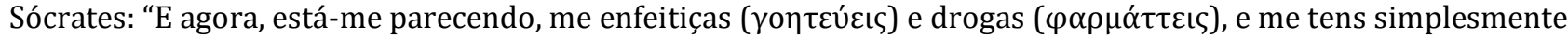

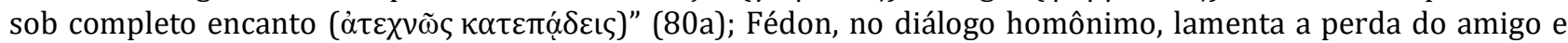

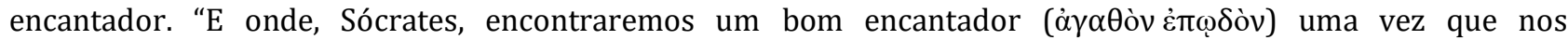
abandonas?" (77d-e).

5 Segundo observa Grimaldi, várias das características que, segundo o historiador e fenomenologista das religiões Mircea Eliade, definem o xamã são cumpridas de uma forma ou de outra no Sócrates de Platão. A primeira delas é a de que o xamã se arroga a cura; a segunda é que o xamã confronta as pessoas com elas mesmas, com suas próprias identidades; a terceira é que o xamã se sente habitado, possuído pelos espíritos, está convencido de ter uma missão divina; e, finalmente, haveria uma quarta característica: o xamã pratica um conjunto de técnicas para libertar-se do corpo. (GRIMALDI, Sócrates, o feiticeiro, 8-10.) Para os nossos propósitos e tendo em vista as ênfases dadas pelo diálogo em questão, destacaremos conjuntamente a quarta e a segunda características elencadas, ou seja, o conjunto de técnicas para libertar-se do corpo como sendo justamente o processo de cura, frisando-se, dentre elas, as destiladas pelo sono. 0 arcabouço cultural grego reconhecia no sono um aliado nos processos de cura tanto somáticas quanto psíquicas, e Platão não deixa de apropriar-se desta sabedoria para construir a sua própria filosofia.

6 Medicina asclepiana é associada à cura através de sonhos e rituais de purificação. Asclépio, herói e deus da medicina, teria se fixado em Epidauro, no Peloponeso, e desenvolvido ali uma verdadeira escola de medicina em cujos métodos o sonho desempenhava um papel fundamental na cura: os doentes dormiam no templo dedicado ao deus e o sonho que trazia a imagem daquilo que proporcionaria a cura lhes era enviado. A prática da cura por meio dos sonhos manteve-se proeminente na medicina grega nos santuários do deus Asclépio, onde pessoas adoecidas dormiam, para receberem sonhos de cura diretamente do deus que vinha visitar os pacientes; as descrições dos sonhos pelos enfermos eram interpretadas pelos sacerdotes que, em seguida, passavam a receita: era o que se pode chamar de mântica por incubação. Os sacerdotes, ademais, frequentemente preparavam poções herbáceas e efetuavam outras curas baseados em suas adivinhações hermenêuticas da proto-retórica do deus da medicina, que geralmente aparecia na forma de um cão ou uma cobra tocando o sonhador na parte do corpo que precisasse ser curada. (ROPP, Os Sonhos da Grécia Antiga, 3). É importante lembrar, ademais, que, no reconhecimento do sono como aliado dos processos de cura, a relação dos sonhos do campo do fazer mântico é transposta, com a medicina hipocrática, para o campo do cuidado do corpo. Sem negar elementos da esfera do sagrado e a existência da profecia em sonho, a medicina hipocrática, descendente de Asclépio, concentrar-se-á em apresentar e explorar o papel dos sonhos, especialmente, como ferramenta de diagnóstico de doenças no corpo do homem. Segundo o autor do tratado, este diagnóstico é possível, pois, uma vez que o sono limita a conexão da alma com o mundo exterior, o objeto de percepção da alma restringe-se ao corpo e ao que ocorre 
sonhos. Nossa suposição, como explicitaremos a seguir, tem como base a abertura do livro IX da República, cujo objetivo é examinar como se transforma o homem democrático

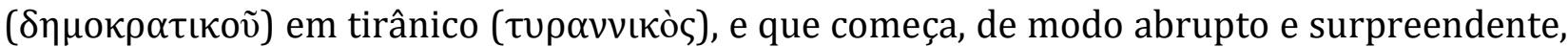
abordando os sonhos.

Estabelecendo um contraste entre a vida de um filósofo e a de um tirano, o tema surge como parte de um longo argumento presente no diálogo acerca da conveniência da vida filosófica. A complexidade da explicação sobre os sonhos contida neste livro da República evidencia uma compreensão por parte de Platão bastante articulada da psicogênese dos sonhos. Já tendo recebido, no livro $\mathrm{V}$, uma explicação ontológica e uma explicação epistemológica 7, os sonhos, agora, são explicados em termos psicológicos. De acordo com Sócrates, em cada um de nós, mesmo naquele pequeno número de pessoas que se mostram comedidas, há uma espécie terrível de desejos selvagens e sem leis, e é nos sonhos que isto se torna evidente $(572 b)$. Sócrates considera que, dentre os prazeres e os desejos, há os necessários e os não necessários, os legítimos e os ilegítimos. Em relação a esses últimos, que provavelmente são inatos, há as condições para que sejam, com o auxílio da razão, corrigidos, o que ocorre mediante os castigos aplicados pelas leis ou através da intensificação dos desejos melhores. Isso, porém, não ocorre com todos os homens, havendo aqueles que têm esses desejos, que são avassaladores, aumentados (571b).

Ao ser questionado por Glaucon sobre de que espécie de desejos se trata, Sócrates responde explicando que são aqueles que despertam durante o sono (ũtvov), sempre que

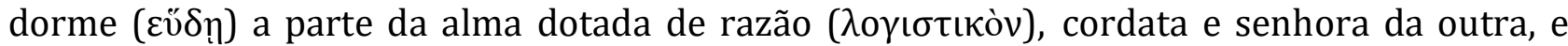
quando a parte animal e selvagem se agita, repudia o sono e procura avançar e satisfazer os seus gostos (571c-d). Apoderando-se das pessoas durante o sono, esses desejos desnecessários acometem todos os seres humanos, embora em intensidades diversas, produzindo sonhos monstruosos ou pesadelos. Em pessoas moderadas, eles são controlados pela razão e pelas leis, enquanto que em tipos intemperantes, como os tiranos, eles são mais fortes e imunes à restrição. São sonhos terríveis que acometem o sonhador quando a parte

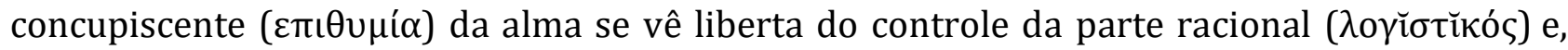
nestas condições, ela ousa fazer tudo sem pudor e reflexão. Sentindo-se livre, sem nenhuma censura ou capacidade reflexiva, nessas disposições, o pensamento da alma adormecida, explica Sócrates, não hesita em unir-se à própria mãe ou a qualquer homem, deus ou animal, em cometer assassínio, nem em abster-se de qualquer alimento ${ }^{8}$.

Sócrates, não obstante, na sequência, também irá assegurar a possibilidade dos sonhos verdadeiros ou mesmo divinatórios, e discorre sobre as condições para a produção destes sonhos. Segundo o filósofo, para se diminuir as visões anômalas ( $\pi \alpha \rho \alpha ́ v o \mu o l)$ dos sonhos

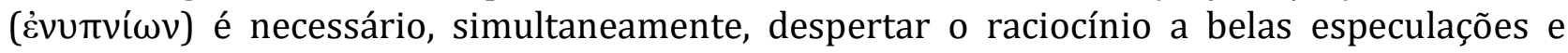

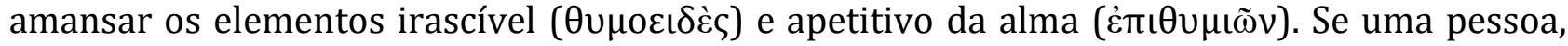

dentro dele e, por conseguinte, a alma, tornada autônoma no sono, observa o corpo e, através dos sonhos, produz um alerta no caso de detectar algum desequilíbrio somático. (ALSINA, As revoluções da alma. Sonho e prodiágnosis no tratado hipocrático 'Da Dieta',126,127).

7 Embora não seja possível abarcar neste artigo as discussões epistemológicas e ontológicas dos sonhos abordadas no Livro V, é interessante ressaltar que lá o sonho recebe por parte de Sócrates uma definição. Afirmando que os amantes de espetáculos vivem em sonho (őv $\alpha \rho$ ), enquanto os filósofos vivem na realidade (ü $\pi \alpha \rho)$, o filósofo declara que sonhar é quando uma pessoa, quer durante o sono, quer desperta, julga que um objeto semelhante a outro não é uma semelhança, mas o próprio objeto com que se parece (476c). Neste sentido, já que a própria vida da vigília é mormente experienciada em estado de sonho, segundo a definição platônica, teremos o cuidado de indicar os sonhos noturnos com palavras que remetem ao sono ou à noite, para efeito de aclaramento.

8 Descrição semelhante pode ser encontrada no Filebo (65e-66a), em que Protarco, mencionando o sonho (őv $\alpha \rho)$ e a vigília (ǔ $\alpha \rho \rho$ ), refere-se à existência de prazeres intensos que nos envergonham e que, ocultando-os o máximo da visão, concentram-se no período noturno. 
possuidora de saúde e de temperança, tranquiliza as duas partes inferiores da alma e põe em

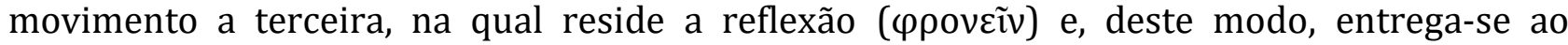
repouso, aí estão as condições para que atinja a verdade ( $\dot{\alpha} \lambda \eta \theta \varepsilon i ́(\alpha \varsigma)$. De acordo com Sócrates, entregando-se à meditação interior e pondo de lado o desejo, seja por carência seja por excesso, deixando-o adormecer sem causar perturbações, e liberando a parte melhor da alma, pura e independente, ela observará e ansiará por perceber aquilo que ignora do passado do presente e do futuro (571e-572b).

A passagem do homem democrático para o homem tirânico é apresentada, tal como se vê, em termos da qualidade e intensidade dos desejos, que são evidenciados nos sonhos. Conforme declara Sócrates, enquanto vivem em regime democrático - que dos regimes é o que tem como valor supremo a liberdade (562c) -, sob a regência das leis e do pai, os homens têm as opiniões monstruosas expandindo-se apenas em sonhos. Porém, quando essas liberdades e esses desejos se expandem, evitando qualquer restrição, esse homem, sob a regência de Eros vivendo à maneira de um tirano em sua alma, numa total anarquia e ausência de leis, passa a ser mesmo desperto ( transição do regime democrático para o tirânico - não cederá perante qualquer audácia e ato monstruoso. Conduzido por Eros como único soberano em sua alma, afirma Sócrates, esses atos perversos e monstruosos serão por ele perpetrados a fim de sustentar a si e à sua tumultuosa comitiva, tanto aquela que, devido às más companhias, penetrou-o desde o exterior, quanto aquela que, originada em si mesmo, libertou-se dos liames uma vez impostos (574d-575a). É desta forma que o indivíduo tirânico comportar-se-á em estado de vigília como se estivesse sonhando, sendo aquele que ébrio, apaixonado, perturbado ou furioso, não só tenta mandar nos homens, como também nos deuses, e imagina ser capaz de tal domínio (573c-d). Nota-se, desta maneira, que tanto no caso dos sonhos dos tiranos, quanto no caso dos sonhos dos homens democráticos, a oposição entre o sonho e a vigília não reflete apenas um estado fisiológico, mas põe em confronto duas condições mentais que podem ou não contrastar entre si - a dos sonhos noturnos e a das experiências espertinas. Se, para a alma democrática, distinguem-se para si esses dois estados, para a alma tirânica, o sonho noturno e a experiência espertina identificam-se entre si, pois, como dito, se, por um lado, as condições que experimenta enquanto dorme não são diferentes daquelas experimentadas pela alma democrática, por outro, ao acordar, a alma tirânica vai experimentar e agir do mesmo modo vivido em sonho. Por fim, o que é dito do tirano, em suma, é que vive uma situação extrema de decadência patológica, cultivando os piores apetites e dominado pelos instintos eróticos e pela paixão desregrada.

É interessante notar que os sonhos são apresentados como relevantes na exibição, como verificamos, tanto do crescimento da tirania ( $\tau \rho \alpha \nu v \iota \kappa o ́ v ~ \varphi \rho o ́ v \eta \mu \alpha$ ), quanto da verdade ( $\dot{\alpha} \lambda \eta \theta \varepsilon i ́ \alpha \varsigma)$ na alma. E a partir da apresentação das condições para a produção de sonhos verdadeiros ou divinatórios, ou seja, para o caso da alma que tranquiliza as suas duas partes inferiores e exercita a reflexão antes de adormecer, observa-se que o movimento é inverso àquele do aparecimento da tirania: o que é da ordem da vigília transfere-se para a esfera onírica e aquele que adormece após ter entregado a alma ao raciocínio e a belas especulações, será orientado pela racionalidade também em sonho. Os seres humanos que, antes do sono, mobilizam a sua faculdade intelectual com pensamentos nobres e satisfazem moderadamente as partes irascível e apetitiva de sua alma, além de serem menos propensos a sonhos perversos, são mais propensos a aprender, em seus sonhos, algo que não sabiam anteriormente acerca do passado, do presente ou do futuro. Se, por um lado, admite-se que todas as faculdades permanecem tendo impacto sobre a formação onírica, que, por seu próprio conteúdo, revela a parte da alma que permanece mais vigilante durante o sono, por outro, quando se põe em movimento a parte racional (e tranquilizam-se as outras antes de se adormecer), esta expande-se nos sonhos pura e independente, podendo, assim, ver a verdade 
em sonhos. E, dessa forma, podemos constatar uma semelhança entre o aspirante a filósofo e um tipo específico de sonhador: assim como o homem democrático, aquele que exercita a sua alma na filosofia não irá embaralhar e fundir seus sonhos com as suas experiências diurnas ${ }^{9}$, porém, diferente daquele que não cultiva a prática filosófica, será capaz de aprender e aperfeiçoar-se com o contributo de suas vivências oníricas.

Observa-se que, a partir do princípio apresentado na República da correspondência estrutural entre a alma e a cidade no livro II (368e-369a), sendo veiculada a concepção de que a cidade constitui uma espécie de homem ampliado, e de que a alma, por seu turno, constitui uma espécie de cidade reduzida, a alma manifestar-se-á como locus prioritário para o qual se deve voltar a fim de compreender o significado das transformações políticas. No interior da alma humana, Platão identifica três elementos ou forças psíquicas principais: o elemento racional ou intelectivo (logistikón), que se caracteriza pelo amor ao conhecimento; o elemento irascível ou ardoroso (thymoeidés), que se caracteriza pelo amor das honras e espírito de competição; e o elemento apetitivo (epithymetikón), que se expressa no desejo sexual e nutritivo. Conforme se estabeleça a hegemonia de um ou outro desses elementos no interior da alma, diferentes costumes se manifestam e, portanto, diferentes formas de governo. As formas de governo, que decorrem uma do fenecimento da outra, se transformam da seguinte maneira: de início, temos a cidade perfeitamente justa, que se caracteriza por estabelecer, na alma dos governantes, uma ordem racional e sadia, fundada na supremacia do princípio intelectivo sobre os elementos colérico e apetitivo, e que tem o saber como o mais elevado valor; em seguida, do declínio e corrupção do melhor regime, irrompe o governo timocrático, sistema político em que a ordem racional da melhor politéia é subvertida e em que o desejo das honras, de vitórias e êxitos guerreiros, impulsionado pelo thymós, se sobrepõe, na elite dirigente, como valor supremo da cidade, à racionalidade e ao amor pelo saber; num terceira momento, da corrupção da timocracia, eclode a oligarquia, regime em que o desejo de riquezas se sobrepõe às honras e aos valores guerreiros; proveniente da decadência da oligarquia, surge, então, a democracia, sistema político caracterizado pela liberdade, o qual decai quando esta torna-se desenfreada e proliferam-se os desejos supérfluos; e, por fim, a tirania, perversão máxima originada do declínio do sistema democrático, na qual triunfam o crime e os desejos ilícitos e bestiais.

Em sua fenomenologia da degeneração da cidade e da alma contida entre os livros VIII e IX, Platão apresentará então quatro espécies de injustiça, as quais se identificam com os regimes políticos e suas respectivas caracterizações psicológicas; bem como para cada tipo de homem em sua respectiva forma de injustiça corresponderá uma paixão peculiar: para o timocrático, é a ambição e o desejo de honrarias; para o oligárquico, é a busca de riqueza; para o democrático, o desejo de uma liberdade sem moderação; e para o tirânico, a violência (544a-e). Sendo assim, enquanto na democracia temos, no plano da economia psíquica, um primado, na psyché dos cidadãos, do elemento apetitivo sobre a parte racional e sobre a parte irascível, o homem oligárquico, por causa de sua avareza ou cupidez, ainda reprime os seus apetites e concede satisfação apenas aos desejos necessários à sua conservação ou subsistência (572c). 0 homem democrático, por sua vez, rompe esse limite e se entrega à satisfação de desejos supérfluos e desvinculados da esfera da necessidade, tais como aqueles relacionados ao luxo, aos prazeres, ao conforto, ao bem-estar e ao divertimento (558b-562a). Como observa Pavianni, o conflito entre desejo e necessidades explica tanto a passagem do homem oligárquico para o democrático quanto do democrático para o tirânico. Porém,

\footnotetext{
9 Atentando-nos à definição do sonho recebida no livro $\mathrm{V}$ e mencionada na nota 8, deve-se considerar que as experiências diurnas dos homens têm a qualidade mormente de sonho em vigília, não escapando disso o homem democrático. A distinção aqui indicada está no fato de que, enquanto este experimenta o contraste entre duas experiências (a vivida enquanto dorme e aquela que passa a experimentar quando acorda), o homem tirânico as iguala.
} 
enquanto o homem oligárquico apresenta ainda alguma forma de continência e moderação, o homem democrático tenderá a ignorar a moderação e a dar livre curso aos seus apetites e paixões, alimentando-se de múltiplos e variados desejos. ${ }^{10}$ A liberação dos desejos é, assim, do ponto de vista psicológico, a causa motriz fundamental que impulsiona o desenvolvimento da democracia, e a liberdade, por conseguinte, é entronizada como valor supremo. ${ }^{11} \mathrm{~A}$ liberdade em excesso, contudo, provoca a escravidão em excesso, quer para o indivíduo, quer para a polis, pois torna os cidadãos avessos à disciplina e servos de seus próprios apetites (564a). Julgando-se inteiramente livres, os homens na democracia em deterioração vão tornando-se insolentes e passam a não manifestar nenhum respeito pelo poder e pela lei: os filhos arrostam os pais, os jovens afrontam os anciãos, os mestres temem seus alunos, os governantes são subservientes aos governados (563a-b).

Finalmente, observa-se que Platão, na República, ao mesmo tempo em que traça um perfil sócio psicológico do tirano, ao longo de todo o diálogo enfatiza a importância do processo educativo na dominação das partes inferiores da alma. A injustiça, segundo o filósofo, sempre traz menos felicidade que a justiça, tanto em relação aos indivíduos quanto em relação à organização da pólis, e a democracia degenerada, pela sua confusão e ausência de ordem e necessidade, enseja a origem da tirania, que, dentre as formas imperfeitas, é a mais deficiente e distante da pólis ideal (562a). Para tornar os homens felizes, aperfeiçoá-los, constituir a cidade justa e evitar a degeneração da polis, o filósofo destaca a necessidade do cultivo da racionalidade e da educação filosófica dos governantes. Por conseguinte, a partir do que foi exposto, notamos no Cármides, em sua escolha pelas personagens em debate e o tema em discussão, justamente a apresentação cênica do problema da passagem e da transformação do homem democrático em tirânico. E tal como explicitaremos a seguir, num período conturbado da democracia ateniense, a alma de Cármides, jovem destacado pelo talento filosófico e poético, e, portanto, com futuro promissor no governo da cidade, é o alvo de uma disputa.

\section{Os sonhos turbulentos da democracia ateniense e a cura filosófica}

Decerto que algumas razões para Platão ter posto Sócrates, Cármides e Crítias para discutirem sobre a moderação ou temperança (sophrosyne) neste momento histórico específico podem ser apresentadas. 0 contexto dramático indicado pelo diálogo situa o encontro e a conversação entre os três logo após a batalha de Potideia, da qual Sócrates retornava e, portanto, no ano de 429 a.C., terceiro ano da guerra do Peloponeso e segundo ano da peste que assolou Atenas. ${ }^{12}$ Um dos motivos seria considerar, debater e divulgar a

\footnotetext{
10 PAVIANI, 0 homem tirânico na República, 44.

11 Lembremos que, na descrição de Os Trabalhos e os Dias, às raças de ouro, de prata, de bronze e de ferro, Hesíodo adiciona uma quinta que não tem um correspondente metálico, mas é feita de carne e osso, que é a raça dos heróis; e que, intercalada entre as gerações do bronze e do ferro, a raça dos heróis interrompe o movimento de decadência contínuo, destacando-se ainda como superior àquela que a precedeu (VERNANT, Mito $e$ Pensamento entre os Gregos, 29). Decerto que a confluência do mito das cinco raças de Hesíodo com a descrição apresentada no livro VIII do declínio em cinco estágios da cidade produz o surpreendente paralelo entre a democracia e a idade dos heróis. Sob essa ótica, deve-se assumir que a democracia é superior, tanto ao regime que o sucede, a tirania, quanto ao que o antecede, a oligarquia; e, assim como se apresenta em Hesíodo em relação à passagem da era de bronze para a era de ferro, a tirania só se instaura se os heróis ou filósofos não se insurgirem.

12 É interessante mencionar que, o culto a Asclépio, o deus-herói da medicina, que vigorou por séculos e que tinha os sonhos como fonte preponderante da cura, segundo observa Koch, atingiu uma enorme popularidade no mundo grego, principalmente a partir do século V a.C., com a Guerra do Peloponeso, quando a sociedade grega sofreu mudanças dramáticas com migrações e epidemias. Portador da saúde e da salvação pessoais nesse mundo, a veneração de Asclépio espalhava-se por toda a Grécia e ligava-se diretamente a seu pai, Apolo, deus
} 
importância da temperança para o bom governo de uma cidade e que, em contrapartida, a falta dela pode assinalar-se como causa das injustiças e desmedidas da Atenas imperial, dos desastres ocasionados pela guerra e dos regimes de terror das oligarquias e tiranias que se formaram. Outra razão seria, como de hábito, as intenções apologéticas de Platão em relação a Sócrates e à filosofia. Visto que Cármides e Crítias, que foram alunos de Sócrates, tornaram-se importantes dirigentes da Tirania dos Trinta (404-403) - regime que sucedeu a democracia ao final da guerra do Peloponeso -, tendo Sócrates sido acusado de ser responsável pelo mau comportamento de alguns de seus seguidores, no pano de fundo do diálogo podemos observar um pertinente debate sobre a atuação da filosofia e do filósofo na construção da cidade.

Considerando-se tanto a correspondência estrutural entre a alma e a cidade na República, quanto a advertência dos médicos trácios, uma vez que a alma dos indivíduos são parte da alma da cidade, não seria possível tratar da alma dos indivíduos sem que se trate antes ou concomitantemente da alma da cidade. Para tanto, a Atenas democrática, tomada de atos de desmedida precisaria, portanto, ser também encantada e ter nela fomentada a temperança? Como tratar a alma da cidade? Tratando da alma dos seus futuros governantes? Seriam Cármides e Crítias futuros governantes de Atenas? Lembremos que, desde Homero a Hesíodo, passando pelas tragédias, o destino dos governantes mostra-se intrinsecamente relacionado com o destino da comunidade e que o cenário da guerra e da peste remete ao problema da injustiça nas cidades, que são castigadas por esses flagelos, decorrentes dos atos de desmedida de seus governantes. Aquele que será um dos piores tiranos de Atenas, Crítias, é um dos interlocutores de Sócrates no diálogo, assim como Cármides que também será um membro da tirania. Este, ademais, é alvo de dores na cabeça, sentidas logo após acordar pela manhã. Como observa Schmitt, ${ }^{13}$ é ironicamente trágico que o personagem que dá nome ao diálogo, jovem destacado por sua moderação e espécie de representante de tudo o que era potencialmente valoroso na aristocracia, tenha caído sob a influência de seu primo, Crítias, tenha chegado a servir à tirania e morrido na última batalha contra as forças democratas vitoriosas, aquelas que estabeleceram o regime que mataria Sócrates. Não obstante, é interessante observar que, embora o contexto dramático do diálogo apresente uma Atenas diante de terríveis prenúncios, Platão parece escrever o Cármides deixando os cenários do que poderia acontecer em aberto (isto é, sem excluir, mas também sem tornar inconteste a tirania futura). Não seriam as pausas para o diálogo filosófico, capazes de suscitar a suspensão momentânea do tempo? Não contribuiriam para conduzir as almas a novas formulações para os velhos problemas, à gestação de novos modos de vida, de novas possibilidades interpretativas e de novos rumos políticos?

Elêntico e aporético, o Cármides é apresentado como uma inspeção estruturada como um teste de definições e tem como um de seus fins o exame do outro com a intenção de produzir nele uma mudança. Como destacamos, tendo Crítias apresentado Cármides como o mais bem-dotado em moderação, Sócrates diz que a questão então é saber se isso é verdade, caso contrário, os encantamentos de Zalmoxis e de Abáride, o hiperbóreo ${ }^{14}$, devem preceder

conhecido também pelo atributo de curar e causar doenças (KOCH, Asclépio, o deus-herói da cura: seu culto e seus templos, 52, 53).

13 SCHMITT, A. A cidade sonhada: filosofia, utopia, sonho e adivinhação, 341.

14 Segundo Grimal, os Hiperbóreos são um povo mítico habitante do extremo norte e a sua lenda relaciona-se com a de Apolo e também a de Asclépio, filho do deus. Zeus receou que Asclépio, devido às inúmeras ressurreições que realizou, alterasse a ordem do mundo e fulminou-o. Após ter matado os ciclopes, artificies do raio que matou seu filho, Apolo teria escondido a flecha usada no centro do país dos hiperbóreos, para onde voou quando nasceu e para onde retorna ciclicamente. Aos hiperbóreos atribuía-se também o conhecimento da magia, o deslocamento no ar, a capacidade de encontrar tesouros, etc; e Pitágoras teria sido considerado encarnação de Apolo Hiperbóreo (GRIMAL, Dicionário da mitologia Grega e Romana, 50, 230). Ábaris, segundo o relato de Heródoto, teria percorrido toda a terra com a sua flecha, sem comer; e Colli acrescenta que, a partir de relatos de 
o remédio. Existindo em Cármides a moderação, ele será capaz de dizer algo a seu respeito e de formar sobre ela uma opinião, pois, segundo Sócrates, quando efetivamente presente em alguém, ela fornece necessariamente alguma percepção (aisthesis) de sua existência, por meio da qual é possível formar uma opinião (doxa) do que ela seja (158e-159a). 0 diálogo termina sem uma definição satisfatória do objeto procurado; porém, ao elenchos refutativo, um procedimento dialógico que opera por meio de perguntas e respostas curtas acerca de uma questão filosófica (pelo seu poder de liberar o interlocutor da ilusão de saber aquilo que não sabe; de retirá-lo do autoengano em relação ao seu saber; e pelo seu poder purgativo) não estaria sendo atribuído um certo poder encantatório e, ademais, a capacidade de produzir a moderação na alma humana? Decerto que é bastante significativo que o Cármides tenha por objeto a busca pela definição de moderação num período tão turbulento da democracia ateniense e os seus participantes sejam nada menos do que duas figuras relevantes da aristocracia e futuros expoentes do regime tirânico. Também podemos dar por certo que Platão, ao reivindicar a superioridade da sua filosofia em relação aos outros modos discursivos influentes e respeitados que circulavam na Grécia, o faz colocando a figura de Sócrates como ícone e herói de sua filosofia. Ademais, enquanto o discurso poético e retórico, em geral, semelhante a uma fórmula mágica e passando a ter força decisória na mente de quem o recebe, induz mais à persuasão e menos à reflexão no interlocutor, o discurso filosófico pretende, com a sua loquacidade, hipnotizar ou encantar de modo a gerar um efeito de suspensão das verdades preconcebidas, obrigando a alma a reordenar a si mesma.

Além do prólogo, o Cármides pode ser dividido em duas partes: a primeira, introdutória, em que Sócrates dialoga com Cármides (158e-162d), e, juntos, colocam em aporia três respostas dadas à questão 'o que é moderação?'; e a segunda, que começa com a entrada de Crítias (162c-175d), que também apresentará três definições de moderação, todas elas por fim consideradas inadequadas - ou, no melhor dos casos, meras aproximações do que a moderação é. A terceira definição apresentada por Cármides ${ }^{15}$ parece ser de autoria de Crítias, apesar de este negá-la: "cuidar um do que lhe é próprio" (161b-162d). Sócrates refuta tal definição e Cármides julga que o autor desta definição talvez não soubesse o que estava dizendo; é aí que Crítias, que já há algum tempo se mostrava inquieto e ansioso em destacarse aos olhos do pupilo e dos demais, entra no diálogo (162c-e). Uma vez introduzido como interlocutor de Sócrates no debate filosófico, Crítias modifica a definição imputada a ele de "cuidar um do que lhe é próprio" por "a prática do bem" (163e), a qual, após o escrutínio

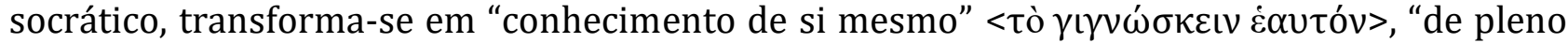
acordo, nesse particular, afirma Crítias, com quem inscreveu no templo de Delfos o conhecido

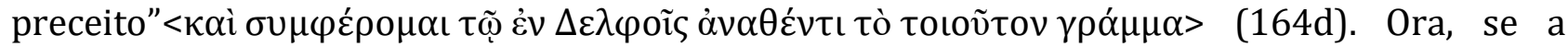
temperança é conhecimento, é evidente que se trata de conhecimento de alguma coisa, insiste Sócrates, pois todos os conhecimentos se referem a algum objeto. Sócrates quer que Crítias estabeleça o objeto desta ciência de si mesmo e exponha o que ela produz. Assim como a ciência da medicina tem como produto a saúde, e a da arquitetura, as casas, sendo a moderação conhecimento de si, Sócrates quer saber o que ele produz; porém Crítias, além de não apresentar a utilidade desta suposta ciência (o bem viver, por exemplo), afirma que há entre ela e as outras uma diferença de natureza. Bastaria que Sócrates aceitasse, a princípio, enveredar pela trilha proposta por Crítias e recusar que o autoconhecimento pertença ao mesmo gênero das outras faculdades cognitivas, que a distinção entre elas se tornaria plausível, já que não é algo de todo impossível e incompreensível (embora nada tenha de simples e enseje inúmeras dificuldades) que o conhecimento seja cognoscível e possa,

Píndaro, é possível constatar que, para além das lendas, Ábaris foi um personagem histórico cuja atividade pela Grécia foi a adivinhação. (COLLI, Sabedoria Grega (I), 404).

$15 \mathrm{O}$ fato de a terceira definição de temperança apresentada por Cármides não ser de sua autoria parece indicar uma certa desistência do jovem em buscar em si e por si a definição almejada e, portanto, não a possuindo, precisar dos encantamentos indicados pelo trácio. 
portanto, voltar-se a si mesmo, ou seja, tenha como objeto a alma, aquela que conhece e é conhecida. ${ }^{16}$ A definição de Crítias, que acusa Sócrates de estar apenas investido em refutá-lo e vencer a discussão, sobre a possibilidade do autoconhecimento não é positivamente demonstrada, mas tampouco é completamente rejeitada - talvez porque Crítias apressadamente modifica-a, apresentando, assim, a última definição do diálogo, restando interrompido o seu exame.

O que, então, Sócrates não aceita na posição de Crítias para, aparentemente, recusar a definição de sophrosyne como conhecimento de si? Podemos dizer que, a contar apenas na defesa de uma proposição, Sócrates e Crítias, a princípio, defendem o mesmo: olhar para dentro de si tem em vista conhecer-se a si mesmo. Porém, cada um deles defende a tese segundo princípios diferentes, sendo elas, as teses, portanto, distintas e com distintas consequências. Crítias, em sua terceira definição, sustenta o princípio de que todo conhecimento estaria dentro de cada um, e bastaria, deste modo, conhecer-se para se ter acesso a todo conhecimento. A solução de Crítias comunga, de um certo modo, com a advertência que Sócrates faz ao jovem Cármides bem no início do diálogo: "olha com atenção para dentro de ti" (160d). Esta, porém, é uma associação utópica (ou seria distópica?) que Crítias estabelece entre a máxima délfica do 'conhece-te a ti mesmo' e a ideia de ser moderado. Conforme a ambição de Crítias, conhecer-se a si mesmo é ter acesso a todo conhecimento, já que o indivíduo seria capaz de "saber o que se sabe e o que não se sabe" (167a). A temperança, nessa perspectiva, é a ciência que conhece as outras ciências e também a si própria, dando a capacidade, ao temperante, de conhecer o que sabe e o que não sabe. Para Sócrates, no entanto, olhar para dentro de si é apenas o primeiro passo para se reconhecer que se sabe o que se sabe e não pretender saber o que não se sabe. 0 saber, deste modo, não partilha apenas de uma dimensão especulativa, mas possui uma dimensão adquirida irredutivelmente da experiência ${ }^{17}$. Sócrates, ao caracterizar o homem moderado como aquele capaz de aprender com mais clareza e de criticar o que aprendeu melhor que os outros (172a-b), bem como o sábio como aquele que sabe que não sabe, sendo este o seu impulso filosófico, sustenta-os como antídotos contra a tirania.

É oportuno, neste ponto, destacar que o Cármides apresenta discursivamente a construção de duas cidades: uma que poderíamos chamar prontamente de distópica e outra, aparentemente, utópica. A primeira (161e-162a) encontra-se descrita após a terceira definição que Cármides oferece à temperança, 'cuidar um do que lhe é próprio'

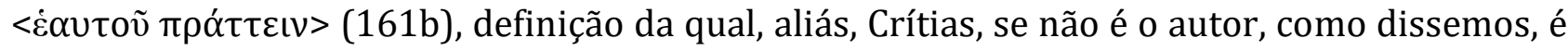
partidário. A despeito de esta definição ser a mesma definição aceita para a justiça na República (433b), bem como das manobras que Sócrates faz com ela, uma cidade em que cada um faz apenas aquilo que lhe diz respeito é ajuizada pelo filósofo, aqui, como uma cidade indesejada e má governada, já que, na ausência da divisão do trabalho, além de não ser possível produzir bens de boa qualidade, não há distribuição de bens, nem qualquer troca

\footnotetext{
16 Complexa e repleta de controversas, não será possível, nesta oportunidade, determo-nos nesta discussão, a qual envolveria, ademais, outros diálogos. Não obstante, nota-se que o diálogo em questão deixa entrever, mas não resolve nem desenvolve, o paradoxo que há no fato de o sujeito ser ao mesmo tempo passivo e ativo, agente e paciente na análise do conhecimento de si. Chama a atenção, no entanto, a alma não se tornar objeto de investigação e análise neste momento da discussão, nem tampouco quando o diálogo se detém na questão de poder ou não haver coisas que têm a propriedade de se relacionarem consigo mesmas (167d-169a); pois, além de um dos temas centrais na maioria das obras platônicas, assiduamente trazida por Sócrates, à alma foi dada grande destaque no início do diálogo. Uma das possíveis razões para esta ausência e o consequente não aprofundamento do debate talvez esteja no fato de que a alma, segunda a dramaturgia filosófica platônica, começasse a receber os seus primeiros contornos ou mesmo porque os interlocutores de Sócrates inviabilizem o aprofundamento.

${ }^{17}$ Lembremos que, mesmo o processo da anamnese das formas, tema ausente neste diálogo, é afirmado como sendo desencadeado pela experiência perceptiva.
} 
entre seus membros (162a). ${ }^{18}$ A segunda cidade projetada, a qual podemos considerar, à primeira vista, desejável ou utópica, aparece a partir da análise da última definição de Crítias, segundo a qual a temperança é, de todos os conhecimento, "o único que não somente é

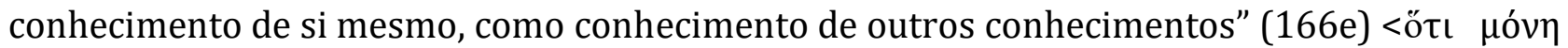

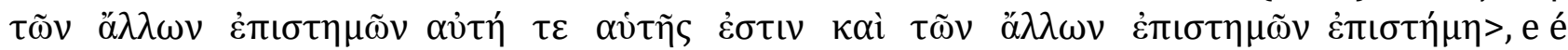
introduzida por Sócrates por meio de um sonho. "Então ouve o meu sonho (ővo $\rho$ ), quer tenha ele passado pela porta de chifre, quer pela de marfim" ${ }^{19}$ (173a). Conforme o sonho de Sócrates, no caso da temperança, tal como definida, ter poder absoluto sobre os membros de uma suposta cidade e todos os seus atos feitos de acordo com a ciência, não lhes escapando qualquer pessoa que pretendesse conhecer alguma coisa, sem, de fato, conhecê-la, isto seria o melhor dos mundos. Nessas condições, com a ciência imune a insinuação da ignorância, viverse-ia mais racionalmente, ficando-se mais saudável do corpo, adquirindo os utensílios necessários com as melhores qualidades e salvando-se dos perigos do mar e da guerra. Além disso, a profecia, segundo o sonho, tornar-se-ia o conhecimento científico do futuro e a temperança a dirigiria, empregando-se apenas os verdadeiros adivinhos para se desvendar o porvir. Sócrates, no entanto, termina o relato do seu sonho, admitindo não compreender como a felicidade participaria desta suposta cidade (173a-d). Sem que possamos fazer uma análise pormenorizada da cidade sonhada, o que se vê, resumidamente, é que, Sócrates, que, a princípio, parece ludibriar-se com tal possibilidade e com as supostas vantagens de uma cidade preservada de erros, tendo-se deixado conduzir pela pressa e impaciência de Crítias, na sequência, coloca a questão do sucesso desta cidade: caso todos os homens fossem temperantes, segundo esta última definição, e, portanto, agissem de acordo com a ciência, lograr-se-ia uma cidade justa e feliz? Segundo Sócrates, não é possível admitir isso sem exame. E qual o benefício disto para a alma: a alma da cidade e de cada um beneficiar-se-iam do mesmo modo? Em outras palavras, o que Sócrates faz aqui é recuperar, para a investigação, a alma, ou melhor, retomar o todo que é o homem, corpo e alma, apresentado no prólogo e ignorado pelo tecnicismo de Crítias.

Sócrates, no Cármides, se, por um lado, ao longo do diálogo, não oferece ensinamentos substantivos sobre a temperança; por outro, alguma instrução é intencionada pela investigação dialética e nas repetidas conduções dos interlocutores à aporia. 0 próprio diálogo termina sem solução, sem uma definição satisfatória do que seja a moderação e sem a cura das opressões na cabeça do jovem. Porém, embora não ensine nem a Cármides nem a seu tutor o que seja a temperança, Sócrates pretende, de certo, inculcar-lhes uma lição, que poderá ou não ser por eles aproveitada - a depender do nível de sua arrogância e do controle que poderão exercer sobre suas próprias paixões. Ao fazê-los ambos conscientes de sua falta de compreensão acerca da temperança, Sócrates, paradoxalmente, busca fornecer aos futuros tiranos uma razão para exercerem o tipo de restrição que a temperança deveria fornecer. 0 encantamento que Sócrates exerce sobre seus interlocutores tem papel importante nesta conversão. 0 encantamento que o filósofo no diálogo exerce sobre Cármides, e sua resolução de segui-lo, isto é, entregar-lhe a alma, nos serve de exemplo, assim como o encantamento que opera sobre o próprio Crítias, que, mesmo sendo mais velho, é levado pelas dúvidas de

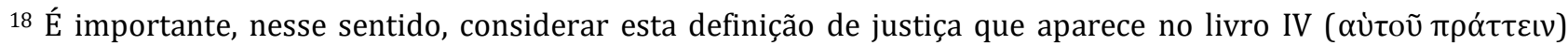
(433b) e que define a estrutura da fundação do estado (433a), juntamente com uma passagem do livro anterior em que a cidade é explicada como tendo origem no fato de que, ao mesmo tempo em que todo homem é vulnerável e depende de muitas coisas, cada um de não é autossuficiente (369b), caso, por sua vez, que remete à existência da diversidade de aptidões para desempenhar diferentes ofícios.

${ }^{19} \mathrm{~A}$ imagem das portas dos sonhos encontra-se, originalmente, nos versos 535-569 do canto XIX da Odisseia, em que Penélope declara que os sonhos, ambíguos, nem todos se realizam, pois há duas portas pelas quais eles podem passar: os que passam pela porta de chifre se realizam; os que saem pela porta de marfim são enganosos e não se realizam.
} 
Sócrates a também ficar em dúvida sobre o que ele acreditava que sabia: "E Crítias, ao ouvir essas palavras e me ver em aporia, assim como aqueles que veem outros bocejando em sua frente experimentam a mesma sensação, pareceu-me ser forçado pela minha aporia a ele

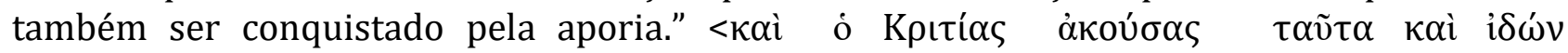

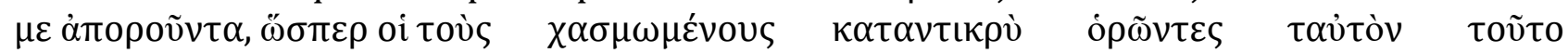

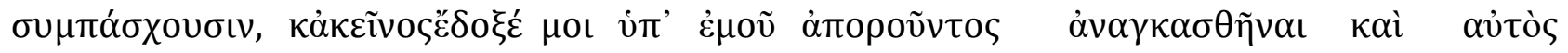

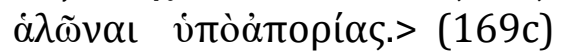

Desde que é forçado a reconhecer que não conhece a natureza da temperança e não pode explicar como ele poderia possivelmente saber se sabe ou não qualquer coisa, tamanha é a aporia a que leva a dialética socrática, o futuro tirano não deveria, deste modo, estabelecer qualquer reivindicação razoável de seus dotes e conhecimentos políticos, necessitando, por este motivo, antes, realizar um reexame de suas próprias crenças e preconcepções, e, portanto, implicar-se no autoconhecimento reivindicado pela filosofia. 0 encantamento de Crítias, contudo, não perdura, pois ele é apressado, inquieto, violento, não controla suas emoções e pensa que sabe o que é a moderação, sem sabê-lo. Crítias, por acreditar-se sábio, não consegue adentrar no encantamento proposto por Sócrates. 0 futuro tirano, ainda que proponha definições mais ou menos socráticas, não as compreende ${ }^{20}$ - e aqui podemos notar o propósito apologético de Platão em relação ao seu filósofo, pois Crítias, apesar de ter sido durante um período discípulo de Sócrates, não aproveitou o seu ensinamento. 0 fracasso, ademais, é também de Sócrates enquanto mestre e curandeiro e, em relação aos prognósticos para as dores do jovem Cármides, é esperável que outras tantas ainda o aguardem.

Consideramos, neste sentido, auxiliados por algumas passagens da República, que Platão, no Cármides, além de iniciar um esboço do perfil sócio psicológico do tirano, coloca em cena a profunda relação que estabelece entre os sonhos e a tirania na alma dos homens. Certamente outras possíveis explicações para as opressões matutinas na cabeça de Cármides já formam aventadas. Para Schmitt,21 a dor de cabeça de Cármides é possivelmente uma alusão metafórica tanto à desmedida da Atenas Imperial, cabeça de um grande império, como também à peste, doença que dizimaria boa parte da população de Atenas e que, segundo o relato de Tucídides, afeta, no princípio, essa parte do corpo humano. Para Pinheiro, ${ }^{22}$ por sua vez, a moléstia na cabeça de Cármides remete ao problema existencial por excelência que é a questão da felicidade e, sendo a cura existencial, ela mesma, filosófica, a dor de cabeça só pode ser eliminada na medida em que há uma entrega total da alma à investigação filosófica, sendo esta capaz de conduzir a alma a uma transformação vital e salutar. Já Gilbert ${ }^{23}$ associa as dores de cabeça matinais de Cármides com uma possível ressaca e afirma que a menção à erva curativa pode ser considerada uma ironia socrática, já que sem a moderação na bebida, a planta não produziria efeito. Dada a proeminência poética da filosofia platônica, todas estas hipóteses são possíveis e igualmente plausíveis. ${ }^{24}$ Participando deste rol de possíveis razões, a hipótese sugerida por nós é a de que as dores de cabeça matinais de Cármides devem-se à qualidade de seus sonhos. E as principais causas dos maus sonhos são, ao que tudo indica, a

\footnotetext{
20 É relevante neste ponto mencionar que uma proposição sustentada por um interlocutor de Sócrates pode ser refutada, não em razão de sua falsidade, mas devido à incompreensão ou compreensão defeituosa por parte daquele que a propõe ou a defende. Ademais, não se contentando com uma definição correta, Sócrates demanda que o seu proponente a explique, exponha as razões que as sustentam e as compreenda.

21 SCHMITT, A. A cidade sonhada: filosofia, utopia, sonho e adivinhação, 226.

22 PINHEIRO, M. R. Filosofia, Saúde, Alma e Corpo no Cármides de Platão, 174.

23 GILBERT, Platonic sophrosyne: Many-headed beast or a simpler creature?, 14.

24 Com a exceção, talvez, da suposição de que as dores de cabeça de Cármides sejam resultantes do seu excesso de vinho e envolvimento em festividades. À princípio, a hipótese parece pertinente, visto que a embriaguez e o vinho podem associar-se ao desequilíbrio das paixões e à alma desordenada de Cármides; porém, sobre esses excessos, não há evidências no texto: a condução do diálogo não o retrata como desmoderado ou impulsivo, além de Crítias apresentá-lo como um jovem moderado.
} 
companhia de Crítias, seu tutor, e a ausência da filosofia (conforme o ponto de vista do autor da obra dramática). Como se evidencia a partir da análise da República, Platão estabelece uma relação considerável e instigante entre a tirania na alma dos homens e o papel dos sonhos na relação entre a doença e a saúde da alma. A transição do homem democrático para o homem tirânico, como assinalamos, explicita-se nas qualidades e intensidade dos desejos, evidenciados nas imagens oníricas; e a formação de sonhos terríveis, que pode acometer todos os homens, é mais forte e habitual nos democratas em degenerescência e nos futuros tiranos, os mais insensíveis a restrições.

Já bem no início do Cármides podemos constatar a intenção de Sócrates em examinar a alma do jovem. Retornando a Atenas de um período em batalha, Sócrates dirige-se à palestra e, após relatar sobre suas experiências em Potideia, quer saber sobre os jovens que se destacam na filosofia e quer conhecê-los. Como vimos, Crítias logo faz Sócrates lembrar-se de Cármides, jovem filho de Gláucon, considerado, além de temperante, bom poeta e inclinado à filosofia, o mais belo de seu tempo. Ao deslumbrar a beleza estonteante de Cármides, Sócrates quer despir a alma do jovem e, tal como observamos, o incentivo para que Cármides se disponha ao diálogo é a menção de que o filósofo o irá curar das opressões na cabeça. É instalada, no início deste diálogo que tratará sobre a moderação, toda uma ambiência que faz ressaltar a beleza do jovem, remetendo-nos, por um lado, aos impulsos de desejo e, por outro, à contenção socrática de si. Sócrates, contemplando a beleza física de Cármides, quer saber se o jovem tem a alma ( $\psi u \chi \eta ́ v)$ tão bela quanto à forma exterior

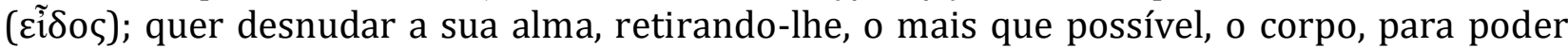
vê-lo mais propriamente - ademais, tal como declara o discípulo de Zalmoxis, são os belos discursos que a tornam bela. "E por que, então, não lhe despimos a alma, para contemplá-la, antes de lhe vermos as formas? Na idade em que está decerto gostará de conversar." < $\tau^{\prime}$ oũv,

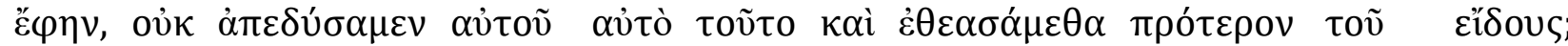

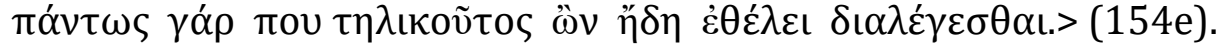

Deste modo, poderíamos conjecturar, valendo-nos da analogia expressa e da explicação da medicina zalmoxiana, que uma alma desprovida de um corpo, bem como uma cabeça desprovida de seus olhos ainda podem ser consideradas como tais, mas que um corpo desprovido de alma e os olhos desprovidos de seu contexto na cabeça não podem funcionar como tais. Entretanto, uma alma sem corpo seria comparável a uma cabeça sem olhos - e uma alma nestas circunstâncias, na ausência do corpo, não pode ver senão coisas que não são deste mundo circundante do aqui e agora. Por um lado, a relação que o diálogo estabelece entre o corpo e a alma é a de vinculação e, portanto, como observa Robinson, ${ }^{25}$ a explicação monista da relação alma-corpo sobrepõe-se à relação dualista, em que alma e corpo são substâncias distintas; mas, por outro, afastando-se temporariamente do corpo, a alma $^{26}$, no sono, transe ou mesmo na perplexidade, experimenta uma espécie de excursão psíquica, a qual Platão parece valorizar, porquanto este excurso é expressão que pode aguçar uma suposta distinção corpo-alma (embora, é claro, corpo e alma, afetando-se mutuamente, não sejam de antemão separados e uma distinção definitiva, se possível, consumar-se-ia apenas da morte ${ }^{27}$ ).

\footnotetext{
25 ROBINSON, A psicologia de Platão, 44.

26 Decerto que esse desligamento ou redução que o corpo experimenta com relação às sensações exteriores quando o sono irrompe, e a afluência de percepções internas afastadas do momento presente ou remotas irrompe, isso ocorre com a contribuição do corpo e suas vivências anteriores; ou seja, o que há não é uma distinção integral entre corpo e alma, mas apenas um distanciamento, ao que se nota, fecundo, segundo Platão.

27 Tema caro a Platão, uma suposta separação e distinções entre corpo e alma enseja muitas discussões e controversas. Contudo, parece interessante apontar para a associação entre filosofia e morte que se apresenta no Fédon, diálogo em que a morte, definida como a separação da alma e do corpo, é identificada como a ocupação dos que se dedicam à filosofia. Algo também pertinente de mencionar presente neste diálogo é a sua cena de
} 
Parece natural que Sócrates tenha sido atraído pela doutrina zalmoxiana, uma vez que se trata de dar relevância à liderança da alma como agente governante do corpo. No entanto, a dor de cabeça de Cármides e a quase irresistível experiência de desejo erótico que Sócrates narra ter sentido ao deparar-se com a figura do jovem Cármides servem como lembretes de que uma alma encarnada - mesmo a alma do filósofo paradigmático - não goza de soberania completa e irrevogável em relação ao corpo. A narrativa de Sócrates sobre a sua superação do desejo erótico em relação a Cármides nos primeiros momentos do prólogo nos lembra a tensão quase que perene entre a alma e o corpo do homem (155c-155e). 0 mesmo Sócrates que, segundo o relato de Alcibíades no Banquete, tem o poder das palavras (215c), bebe sem embriagar-se (214a), que demonstrou temperança e autocontrole para resistir aos diversos planos por ele articulados para deitar-se com o filósofo (217a-219d), que não se permite dominar pela paixão, nem pela beleza do corpo ou pela cobiça por riquezas (219e), e que, no campo de batalha, na expedição a Potideia, aturdiu a todos pela coragem diante da morte e com sua capacidade de suportar a fome e o frio (220a-e), agora mostra-se suscetível às paixões corpóreas, e isso aponta para a existência humana enquanto uma alma conectada a um corpo.

Como salientamos, Sócrates diz a Cármides que, durante sua temporada na guerra, relacionou-se com o discípulo do deus Zalmoxis que lhe teria ensinado certas práticas mágicas de origens trácias, que poderíamos afirmar, xamânicas. Pode não ser crível que o filósofo tenha passado por uma iniciação espiritual em meio à guerra, contudo, para corroborar o seu relato, temos, dentro da dramaturgia platônica, o testemunho novamente de Alcibíades no Banquete, companheiro seu na excursão à Potideia, que conta os feitos surpreendentes de Sócrates. Além dos mencionados acima, Alcibíades relata - talvez o transe socrático de maior duração - que o filósofo teria permanecido imóvel durante ininterruptas 24 horas, insensível às exigências normais do corpo e a tudo o que ocorre em torno dele, ou seja, totalmente ausente (220c-d). Alcibíades conta que, na expedição, Sócrates, além de permanecer por longos períodos em contemplação sem mover-se, surpreendeu resistindo de maneira inigualável às intempéries. Segundo o estratego apaixonado, após este dia em transe em Potideia, Sócrates volta à 'normalidade', faz uma prece ao sol e depois age como se absolutamente nada tivesse transcorrido. Deve-se notar, neste sentido, que a maneira de retomar contato com a realidade ordinária denota o caráter místico da experiência, assim como a oração ao sol indica uma relação de Sócrates com a natureza e os elementos que não provém da religião grega clássica. 0 suposto xamanismo socrático instilado nos diálogos é comumente tratado como uma metáfora de Platão; porém, seja uma metáfora, seja uma analogia, Sócrates, no Cármides, - assim como os xamãs pretendem curar com seus encantamentos - pretende-se capaz de curar a vista, a cabeça e a alma de Cármides através do encantamento filosófico. Como Sócrates mesmo declara no seu último diálogo antes de beber a cicuta, ao longo de toda a vida, visitou-o um sonho ( $\dot{\varepsilon} v u \pi v i ́ \omega v$ ) recorrente que lhe

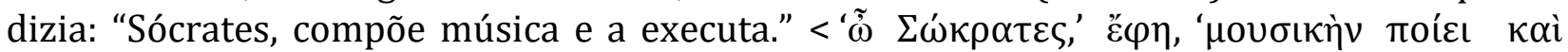

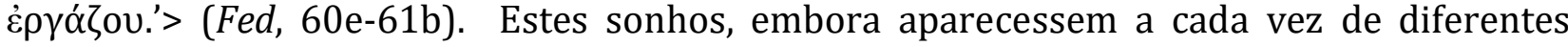
maneiras, tinham para ele sempre um e o mesmo significado, o de compor e executar música, e como sempre considerou a filosofia a mais alta música, nunca deixou de seguir o comando do sonho. 


\section{Referências}

ALSINA, J. As revoluções da alma. Sonho e prodiágnosis no tratado hipocrático 'Da Dieta'. São Paulo: USP, Tese de doutorado, 2015. Disponível em: <https://teses.usp.br/teses/disponiveis/8/8143/tde-18112015-115324/es.php > Acesso em: 13 set. 2020 .

COLLI, G. A sabedoria grega (I): Dioniso, Paolo, Eleusis, Orfeu, Museu, Hiperbóreos, Enigma. São Paulo: Paulus, 2012.

GILBERT, P. R. Platonic sophrosyne: Many-headed beast or a simpler creature? (Tese de Doutorado) Oslo: University of Oslo, 2010. Disponível em: <https://www.duo.uio.no/handle/10852/25150 > Acesso em: 13 set. 2020.

GRIMAL, P. Dicionário de mitologia grega e romana. Rio de Janeiro: Bertrand Brasil, 2011.

GRIMALDI, N. Sócrates, o feiticeiro. São Paulo: Edições Loyola, 2006.

HERÓDOTO. Histórias. Tradução de Maria de Fátima Silva (1-144) e Cristina Abranches Guerreiro (145-205). Lisboa: Edições 70, 2000.

KOCH, S.R. Asclépio, o deus-herói da cura: seu culto e seus templos. Revista do Museu de Arqueologia e Etnologia, São Paulo, Suplemento 12: 51-55, 2011. Disponível em: <http://www.revistas.usp.br/revmaesupl/article/view/113567/111522> Acesso em: 13 set. 2020 .

PAVIANI, J. 0 homem tirânico na República. Hypnos. n. 9 - 2º sem. (2002). São Paulo, p. 39-56. Disponível em: <https://hypnos.org.br/index.php/hypnos/article/view/131/133> Acesso em: 13 set. 2020 .

PINHEIRO, M. R. Filosofia, Saúde, Alma e Corpo no Cármides de Platão. In: Princípios, Natal, vol. 12, nos 17-18, jan./dez. 2005, p. 173-182. Disponível em: <https://periodicos.ufrn.br/principios/article/view/533/463>. Acesso em: 13 set. 2020.

PLATÃo. Banquete. Tradução de Jose Cavalcante de Souza. São Paulo: Abril Cultural, 1972. (Os Pensadores).

PLATÃo. Cármides, Critão. Tradução de Carlos Alberto Nunes. Belém: UFPA, 1980 (Coleção Amazônica).

PLATÃo. Filebo. Tradução de Fernando Muniz. São Paulo: Loyola, 2012.

PLATÃo. Fédon. Tradução de Carlos Alberto Nunes. Belém: UFPA, 1980 (Coleção Amazônica).

PLATÃo. Mênon. ed. bilíngue. Tradução de Maura Iglésias. Rio de Janeiro: Ed. PUC-Rio; São Paulo: Loyola, 2001.

PLATÃO. República. Tradução de Maria Helena da Rocha Pereira. 9. ed. Lisboa: Fundação Calouste Gulbenkian, 2001.

ROBInSON, T. M. A psicologia de Platão. Tradução de Marcelo Marques. São Paulo: Loyola, 2007.

ROPP, C. P. Os Sonhos da Grécia Antiga. Trad.: Leonardo T. de Oliveira. A Hermeneutic and Rhetoric of Dreams', Janus Head, Vol. 3, No. 1, (2000).

SCHMITT, A. A cidade sonhada: filosofia, utopia, sonho e adivinhação. Kléos. v. 16-17. Rio de Janeiro: UFRJ, IFCS, Pragma, p. 215-230. Disponível em: <https://periodicos.ufrn.br/principios/article/view/533/463>. Acesso em: 13 set. 2020.

VERNANT, J-P. Mito e Pensamento entre os Gregos. São Paulo: Paz e Terra, 2002. 